\title{
Los pueblos del salitre
}

\section{The villages of niter}

$\mathrm{E}$ n 1879 estalla la Guerra del Pacífico, cuyas trascendentales consecuencias en la vida económica y política chilena se aprecian hasta hoy. El dominio adquirido por Chile sobre las provincias de Antofagasta y Tarapacá se tradujo en una poderosa inyección de riquezas, que puso fin a la crisis económica que se arrastraba desde 1874. El comercio internacional, tanto en importaciones como en exportaciones y cabotaje aumentó de 65 millones de pesos a 135 millones en diez años, y los ingresos fiscales pasaron de 15 millones de pesos a 53 millones en el mismo período.

Sin embargo, la industria del salitre supeditó todas las demás ramas de la producción, consolidando la calidad de país monoproductor de Chile, situación que motivó el llamado de alerta de la Sociedad de Fomento Fabril, que en su boletín número uno de enero de 1889 decía: "Pasará el salitre y tal vez no nos dejará sino el remordimiento por la escasa utilidad de la renta que produjo. Pero cada fábrica nueva nos hará más ricos y fuertes, llamando al trabajo a ese numeroso elemento social que en otros países vive de su esfuerzo individual".

$\mathrm{El}$ auge de esta industria produjo una masiva migración de trabajadores y sus familias desde las zonas rurales del sur hacia el Norte Grande, formándose entre Pisagua y Taltal una sociedad muy particular, donde sus habitantes debieron adaptarse a las complejas condiciones laborales
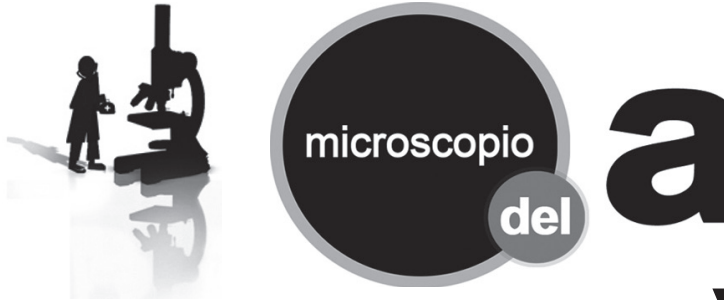

\section{y la cultura}

propias de la minería del salitre, así como aprender con ingenio y mínimos recursos, a sobrevivir en las duras condiciones del desierto más seco del mundo.

Entre 1895 y 1899 se registró la existencia de 48 oficinas salitreras, en las cuales trabajaban más de 18.685 operarios; entre 1910 y 1914 esta cifra se triplicó, ascendiendo a 118 oficinas y 46.470 trabajadores. La cantidad de personas que vivía en una oficina salitrera variaba de acuerdo a varios factores, como los procesos productivos que allí se ejecutaban, la compañía a la que pertenecía y el cantón salitrero al que correspondía. Cada cantón (unidad territorial que aglutinaba un grupo de campamentos) tenía un poblado central, donde los trabajadores y sus familias podían acceder a servicios que el campamento no ofrecía: espacios de diversión, servicios religiosos, sanitarios, educación, cementerios, medios de comunicación, comercio, etc.

El líder obrero pampino Elías Lafertte cuenta en sus memorias: "Por aquel tiempo, el fenómeno más característico de la pampa era emigrar de una a otra oficina. Nadie echaba raices en un sitio, y era muy dificil hallar, como ocurre en los campos, a gente que ha envejecido en un mismo sitio. Las oficinas se abrían, se cerraban, volvian a abrirse. Los pampinos se cambiaban por ganar unos pesos más, o porque les interesaba una mujer en una oficina a varios kilómetros de distancia. Yo mismo, a los veinte años había trabajado en una larga cadena de centros salitreros. Esta vez nos fuimos a Puntunchara, porque mi abuela había tenido dificultades para la mantención de su vaca en Aguasanta".

El impacto de la crisis económica de 1930 puso fin al ciclo salitrero y, con ello, a una forma de vida única en el mundo, el de la pampa calichera.

Ernesto Payá

Hospital de Carabineros, Santiago, Chile

\section{Referencias bibliográficas}

1.- Memoria chilena: La vida en la pampa salitrera: http://www.memoriachilena.cl/temas/dest. asp?id=vidacotidianacampamento (accedido el 30/10/2012).

2.- Ramírez Necochea Hernán. Balmaceda y la contrarrevolución de 1891. Editorial Universitaria. $3^{\text {a }}$ edición. Santiago. 1972.

3.- Lafertte Elías. Vida de un comunista. Editorial Austral. Santiago. 1961.

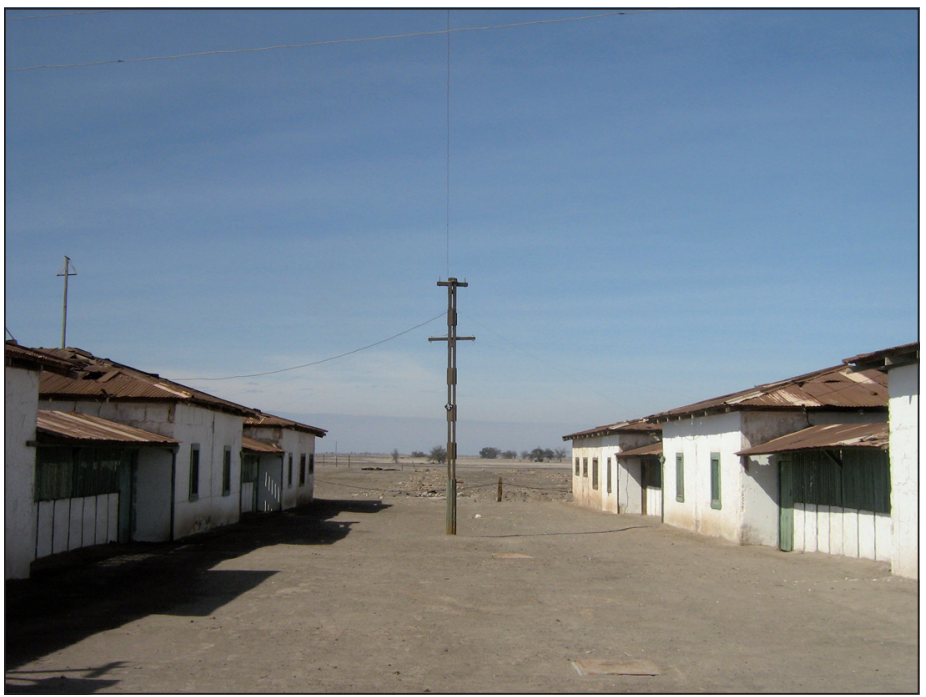

Figura 1. Calle y viviendas de obreros. Oficina Humberstone. Foto E. Payá.

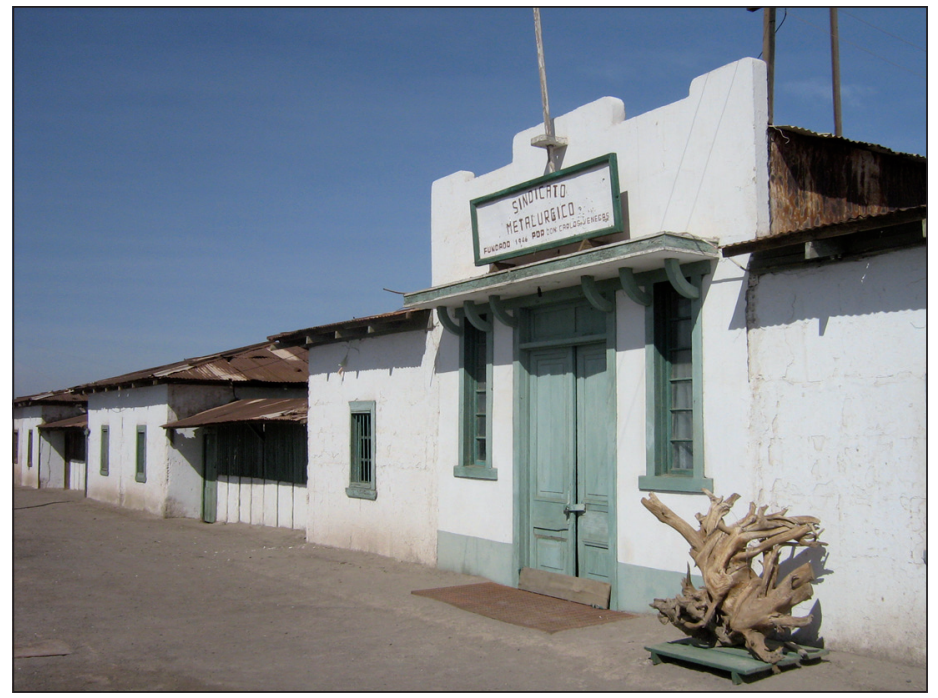

Figura 2. Sede sindicato obrero. Oficina Humberstone. Foto E. Payá. 